\title{
West German research agencies oppose new embryo law
}

Munich

THE two principal West German research organizations have issued long-awaited position papers in response to a proposed law which forbids research on human embryos. Both the Deutsche Forschungsgemeinschaft (DFG) and the Max-PlanckGesellschaft (MPG) support the spirit of the law but would prefer that some experiments be allowed under the guidance of a committee of scientists, ethicists and theologians.

The papers came in response to a draft law first made public in April 1986, under which all research on human embryos and the genetic manipulation of human germline cells would be subject to criminal penalties, including imprisonment. The Justice Minister, Hans Engelhard (Free Democrat), is trying to push the new law through parliament by June.

Under the proposed law, procedures such as injuring or killing human embryos (except in the context of an abortion) are punishable by up to five years in prison. Cloning of embryos as well as creating chimaeras (hybrids) out of more than one

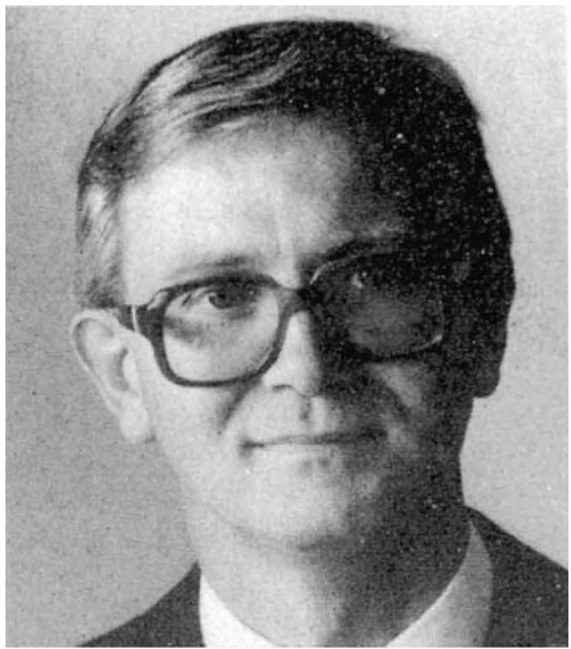

"Self-regulation is more effective than passing a law", says DFG president Hubert Markl.

human embryo or out of human and animal germ-line cells are similarly punishable. Experiments on aborted fetuses or eggs fertilized in vitro without the intention to implant the egg in a woman's uterus are punishable by up to three years in prison.

The proposed law goes much further than recommended by a series of parliamentary committees. "Not everything that is technically possible should be allowed," Engelhard has said. The Justice Ministry also intends to pass a law against "mothers-for-hire".

The two science organizations want to keep jurisdiction over embryo research under the control of doctors and scientists.
President Heinz Staab of the MPG said the proposed law "fixes conditions too strictly and does not allow for any flexibility." The MPG position paper goes further, stating that the introduction of criminal penalties will frighten scientists away from potentially valuable research.

The report also complains that the law would punish doctors for trying innovative treatments for certain diseases and force them to practice "defensive medicine". Perhaps worst of all, the law would not be as well prepared to adapt itself to new research developments as would a panel of scientists. However, the MPG paper recognizes as "irresponsible" procedures such as the cloning of human beings or interspecies hybridization.

The DFG, in a more general statement, called for limited and strictly regulated exceptions to the proposed law. DFG President Hubert Markl said that one cannot discount the possibility that such research might continue anyway despite the harsh penalties. Markl criticized the irresponsibility of forbidding research in West Germany that will probably be done elsewhere. He said it would be "almost immoral" to let another country do the research and then use the results.

The MPG and the DFG both point out that the proposed law is inconsistent with West Germany's liberal abortion law. "It seems inconsistent to researchers," said Markl, that 100,000 abortions are performed each year but that the law "forbids the use of an embryo in a research experiment that will help other people".

Steven Dickman

\section{Money from supermarket chain ploughed back into plant research}

\section{London}

IN what is almost certainly the largest private gift ever made in Britain to support the plant sciences, Mr David Sainsbury, of the grocery family, is to give $£ 15$ million, through the Gatsby Charitable Foundation which he endowed, to support research in molecular plant pathology. The money will be used to set up, and support for at least ten years, a new international laboratory located at the John Innes Institute in Norwich. The first staff will be appointed later in the academic year, and work should start in October.

Announcing the gift, Mr Sainsbury, finance director of J. Sainsbury PLC, said that molecular plant pathology was currently an area of great scientific opportunity and offered a significant hope of producing practical benefits, in reducing the cost of crop plant disease, that would be of importance for both industrialized and developing countries.

The object of the initiative, developed from collaboration between the Gatsby Foundation, the John Innes Foundation, the Agricultural and Food Research Council (AFRC) and the University of East Anglia, is to provide long-term support for scientists at the highest international level of achievement. The new laboratory, which plans to pay the salaries needed to attract scientists of outstanding ability, is intended as an expression of confidence in the quality and value of British science at a time when many young scientists are tempted to work abroad.

The John Innes Institute, a partner member of the AFRC's Institute of Plant Science Research, was chosen as the site of the new laboratory because of its existing strengths in the study of bacterial and viral diseases of plants by the techniques of molecular biology.

The Sainsbury laboratory will be based on small core of semi-permanent staff, intended to be "highly innovative scientists", whose studies of host-parasite interaction will be funded in the long term. But there will also be provision for a large proportion of research students,

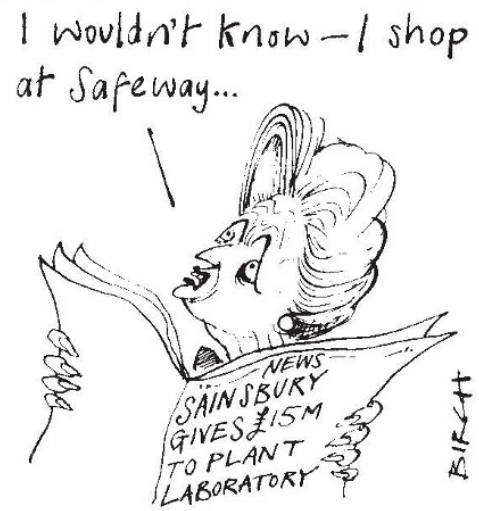

visitors and research fellows among the projected thirty or so staff. Some staff seconded to the laboratory will have their salary paid to enable their home institution to replace them. Individuals will decide whether to pursue the practical applications of their research, which will be made widely available in a way that returns benefit to the laboratory itself.

Administration will be guided by a council, on which the three leading scientific staff will serve with a panel of independent scientists of international stature, chaired initially by Professor Harold Woolhouse, Director of the John Innes Institute. The overall aim will be to give active scientists a decisive role in management.

Giles Courtice 